\title{
Homo viator
}

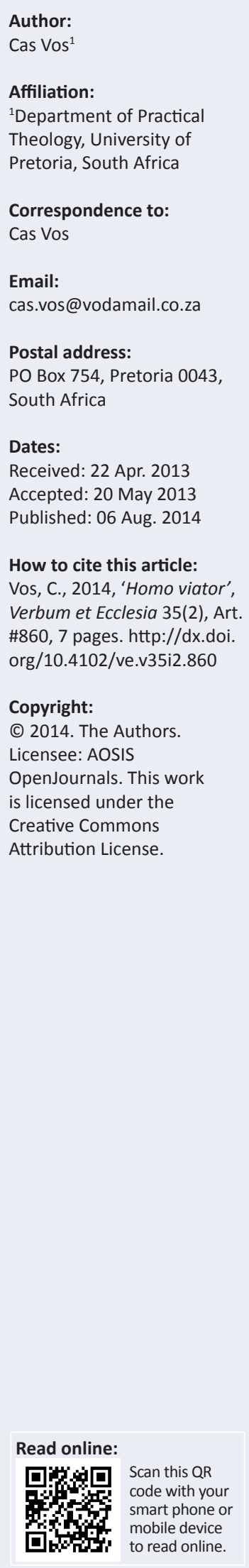

Homo viator. This article investigates the uniqueness of a metaphor. The golden thread throughout this article is the contemplation of a metaphor as a journey. The creative thinking of Paul Ricoeur, Johan Degenaar, Bertie du Plessis and Adelia Carstens on the metaphor is recognised and explored in this article. Julian Müller's use of the metaphor as journey is also discussed. The metaphor as a journey in Homeros, the Old Testament as well as the New Testament is investigated. The binding force of metaphors in language is also considered. The essence and expressiveness of a metaphor are explained by means of several different examples. The destination of this journey finds its conclusion in a poem.

\section{Inleiding}

In 1964 is 'n feesbundel aan prof. C.K. Oberholzer tydens die viering van sy sestigste verjaarsdag opgedra. Die titel van die bundel is Homo viator (1964). Ek het dieselfde titel vir hierdie artikel gekies omdat prof. Oberholzer by my en Jan du Rand 'n liefde vir die filosofie gekweek het. En natuurlik omdat dit die benadering, wat Julian Müller in sy beoefening van die pastoraat volg, raak saamvat. Sy boek, Reis-geselskap. Die kuns van verhalende pastorale gesprekvoering (2000), is 'n uitvloeisel van sy benadering tot die pastoraat as 'n reis. Ek dra die artikel met waardering op aan prof. Müller as dank vir 'n akademiese en kollegiale reis wat dekades geduur het.

Tydens ons eerste 3 jaar in die Departement Filosofie het ek en Jan du Rand nie net die Griekse filosowe, Immanuel Kant en die eksistensiële filosowe soos Sören Kiergegaard, Gabriel Marcel, Karl Jaspers, Martin Heidegger en Jean-Paul Sartre gelees nie, maar ook A. Vloemans (1949). By hom het ons geleer dat die mens as reisiger probeer en faal, val en weer opstaan. Hierdie beweeglikheid stel hom in staat om sy lot in sy eie hande te neem: hy beskik oor die vryheid om van die hede na die toekoms te gryp. Op dié manier vorm hy die toekoms vooruit. Hierdie vryheid sluit alle moontlikhede in - ook die vryheid tot ondergang. Sodoende beweeg die mens altyd met die afgrond langs hom. Daarom is hierdie wese vir homself nie alleen 'n vraagstuk nie, maar nog meer, 'n waagstuk. Hy kan die hoogste pieke bereik, maar hy kan ook alles verloor, naamlik homself. Dan sal die mooiste droom uitgedroom wees en ongebreidelde dierlikheid op aarde heers (Vloemans 1949:245).

Met Vloemans in herinnering en Julian Müller steeds op reis, al is die pad nou anders, ondersoek die artikel terselfdertyd reis wat ook 'n metafoor kan wees.

Voordat daar aandag aan voorbeelde van die metafoor as 'n reis in die Griekse wêreld, die Ou Testament en die Nuwe Testament gegee word, en hoe die metafoor in Julian Müller se Reisgeselskap neerslag vind, moet die dwingende vraag van wát onder die term metafoor verstaan word, beantwoord word.

\section{Metafore as vonkpos}

Metafore is verbeeldingsvonke. In die film Il Postino word dit geïllustreer. ' $n$ Posbode is die draer van nuus. Soms is dit slegte nuus, veral as hy vensterkoevertjies aflewer. Ander kere is die goeie nuus: ' $n$ brief van ' $n$ vriend, ' $n$ vriendin en veral van 'n geliefde. Dan is hy die draer van vonkpos. Il Postino handel oor 'n toegewyde posbode, Mario Ruoppolo. Met sy fiets lewer hy getrou die pos af op die Italiaanse eiland Cala di Sotto. Een van die ontvangers, die beroemde digter Pablo Neruda, woon hier teen 'n steil heuwel in politieke ballingskap.

Op 'n goeie dag raak Mario, soos dit met menige jongman nou maar gaan, verlief op'n beeldskone meisie, Beatrice Russo. Hy verloor sy hart en staar sprakeloos na haar. Om sy liefde aan haar te verklaar het hy digterlike woorde nodig. Die digter moet hom met Beatrice in aanraking bring. By Neruda leer Mario die krag van metafore ken. As die wantrouige, onaantreklike tante van Beatrice iets hiervan hoor, roep sy, hand voor die mond, verskrik uit: 'Metáforo!' - asof dit 'n 
besmetlike siekte is. Maar Mario leer dat sy tong nie net daar is om seëls te lek nie, maar veral om metafore te munt. Metafore is vlerke wat die liefde dra.

Maar wat is 'n metafoor? Dit is 'n manier om oor en met die Onsienlike te praat.

\section{Die metaforiese landskap Enkele flitse van filosofiese denke oor metafore}

Wolterstorff (1999:562) wys daarop dat metafore'n filosofiese onderwerp is wat reeds sedert die tyd van Aristoteles die spraakfiguur is wat meer as enige ander deur taalfilosowe bespreek is. Een tema wat prominent in hierdie besprekings tot en met die negentiende eeu voorkom, is die siening dat metafore 'taalversierings' is. Metafore is dekoratiewe moontlikhede ter wille van retoriese en estetiese funksies. Volgens hierdie beskouing dra metafore niks by tot die verstaanaspek van die diskoers nie. Hulle is bloot kleur, sensasie en emosionele neerslag. Dit was kenmerkend van die filosowe van die pre-Verligtingstyd en die Verligting om daarop aan te dring dat, alhoewel filosowe dalk goeie rede het om hul begrippe deur middel van metafore oor te dra, dit verstandiger is om nie in metafore te dink nie. Inteendeel, hulle kan en moet daarsonder klaarkom, want metafore kan mislei.

Die uitstaande kenmerk van omtrent alle teorieë en besinnings oor metafore sedert die Romantiek tot in ons eie tyd is die verwerping van die siening dat metafore as opsionele versiering beskou kan word.

Postmoderne taalfilosofie sedert Nietzsche sien metafore nie net in die besinning van teologie en godsdiens nie. Daar is oral metaforiese spore. Nietzsche (vgl. Schoeman 2004) gaan selfs sover as om te beweer dat alle taal metafories is en die waarheid self bloot 'n leër (weermag) van metafore is.

Sharpe (1995:355) wys daarop dat die beginpunt in die filosofiese besprekings oor die verwoordbaarheid van metafore in letterlike taal moontlik is. Kortom: is metafore vertaalbaar tot 'n dinamiese ekwivalent? Daar is verskeie teorieë hieroor. Volgens die substitusieteorie word veronderstel dat 'n metafoor ' $n$ letterlike ekwivalent verteenwoordig. Die uitdrukking 'God is 'n Vader' kan uitgebrei word tot na 'n tegnies vergelykbare frase soos: 'God is 'n Vader wat betref die volgende eienskappe van vaders: liefde, sorg, trou, en so meer.'

Dit klink voor die hand liggend, maar ná die invloedryke referaat van Max Black (1962) waarin hy die bogenoemde teorie met die sogenaamde 'interaksieteorie' probeer vervang het, het filosowe al hoe meer waardering ontwikkel vir die feit dat verskillende mense verskillende eienskappe in hul vertolking van metafore uitkies. Mense het, vanweë persoonlike verwysingsraamwerke, verskillende assosiasies met konsepte (soos 'God' en 'vader') en lees verskillende oorvleuelings en gemeenskaplikhede in die lig van hierdie meervoudige perspektiewe.
Ons weet egter nie met sekerheid presies wat die skrywer met die betrokke metaforiese terme geassosieer het nie. Gebruikers van metafore het nie altyd helderheid oor hul gedagtes nie. Hul gedagtes dwarrel ook maar soos rook. Verder is die skrywer nie vir 'n onderhoud beskikbaar nie en word die bepaalde metafoor dalk ook nie meer in ons eie konteks algemeen gebruik nie. Die Bybelskrywers se verwysingsraamwerk is boonop heel waarskynlik in baie opsigte anders as ons s'n. Ons kan nooit heeltemal seker wees dat ons dieselfde assosiatiewe betekenis aan die betrokke woorde heg nie. Ons idees oor en ervarings van konsepte soos God en vader is immers nie meer dieselfde as in Bybelse tye nie, ondanks gemeenskaplikhede.

Metafore se interpretasie word beïnvloed deur die inlees van die assosiasie van die leser.

Metafore verteenwoordig die groeipunte in taal. Ons taal is deurdrenk van metafore. Talle metafore het egter tot stomp metafore verslyt omdat hulle met verloop van tyd 'n meer letterlike begrip verkry het. Dit beteken nie dat verslete metafore nie weer skerp gemaak kan word nie. Nie net in die godsdiens nie, maar ook in die taal van die wetenskap is daar talle naamwoorde, werkwoorde, en so meer wat 'n metaforiese verwysingsraamwerk veronderstel, hoewel jare van gebruik en herinterpretasie die betekenis in baie opsigte skynbaar verletterlik het.

Gesien teen die eis van logiese taalgebruik is die metafoor vir baie filosowe 'n geval van woordmisbruik, 'n noodsaaklike euwel of 'n blote versiering, en daarom nie geskik vir die uitdrukking van proporsionele 'waarhede' nie (Gräbe 1992). Selfs in die sestigerjare vind die filosoof Max Black (1962) dit byvoorbeeld nodig om die gebruik van metaforiese taalgebruik in filosofiese tekste te verdedig.

\section{Peiling van 'n metafoor}

'n Kenmerk van 'n gedig is sy tekstuur. Tekstuur is die taal waarmee die gedig geweef is. Dit is die kleur van en die vonk in taal. Net soos prosa, gebruik poësie taal. Maar die digter kleur taal anders in as die skrywer van prosa. Wat is die kenmerke van poëtiese taal? Soos 'n rivier vol water is, is 'n gedig die ene beelde en metafore.

Wat is 'n metafoor? Volgens Aristoteles, beteken metafoor om aan iemand ' $n$ naam te gee wat aan ' $n$ ander persoon behoort. Die woord metafoor kom van die Griekse woorde meta (oor) en pherein (dra). Hieruit is die Latynse woord metaphora geskep, wat 'figuurlik' beteken (Degenaar 1970:294). 'n Metafoor is die oordra van energie, 'n wyse van interpretasie, 'n saak van identiteit en verskil (Hirsch 1999:13).

In The Philosophy of Rhetoric (1936) onderskei I.A. Richards die twee dele van 'n metafoor deur die terme tenor en vehicle. Die tenor dui op dit waaroor gepraat word. Dit is die subjek. Die vehicle staan vir die wyse waarop dit gedoen word en dra die gewig van 'n verglyking. As Macbeth sê: '... life is but a walking shadow', dan is 'life' die tenor en 'walking shadow' die vehicle (Hirsch 1999:289). 
'n Metafoor handel oor uitbeelding en verbeelding (vgl. Heitink 2011:341-343 en Degenaar 2011). As 'n metafoor 'n verhouding tussen twee domeine skep, word nuwe assosiasies en verbindinge tot stand gebring. 'n Metafoor maak ons оё oop om te sien. Die resultaat is meestal verrassend en vreemd. 'n Metafoor is soos ' $n$ paling: dit is glad, vinnig, glibberig en vars. Die metafoor maak taal nuut en lewendig. Die wonder van 'n metafoor is dat dit mense in staat stel om sake te verbind wat andersins nie die geval sou gewees het nie. Dit skep die moontlikheid om nuut na sake, die ander en die wêreld te kyk (vgl. Degenaar 1970; Du Plessis 2006). Die leser word uitgenooi om die krag van metafore te ontdek. Dit kom in die gedig van Rochelle Kraut (Paglia 2005:210) voor.

\section{My Makeup}

on my cheeks I wear

the flush of two beers

on my eyes I use

the dark circles of sleepless nights

to great advantage

for lipstick

I wear my lips. (Rochelle Kraut, Paglia 2005:210)

Metafore is soos dinamiet. Dit ruk nuwe wêrelde oop waarna die leser met verwondering kan kyk.

Na my mening is daar 'n noue verwantskap tussen metafore en vergelykings. Die element van gelykstelling, wat die grondslag van die vergelyking is, word in die geval van 'n metafoor uitgeskakel. Nogtans sou ek selfs van 'n familieverwantskap praat. In die geval van 'n vergelyking gaan dit om die oordrag tussen twee terme. Die oordrag berus op die waarneming dat die vergelyking iets verduidelik deur twee sake of persone met mekaar te vergelyk. Ek gee 'n voorbeeld: God is soos dou. Hiermee word te kenne gegee dat God met dou (wat aan mense bekend is en sekere assosiasies oproep) vergelyk kan word.

In die geval van 'n metafoor gaan dit om die uitbeelding en verbeelding. Wanneer ' $n$ metafoor ' $n$ verhouding tussen twee gebiede of persone daarstel, word nuwe assosiatiewe samehang tot stand gebring. Die metafoor maak ons oë oop vir 'sien soos'. Die uitkoms is meestal verrassend en vreemd. Dit plaas die ontvanger in 'n nuwe lig (Bons 2004:236).

Black (1962) beskryf die metafoor as 'n 'filter' wat net bepaalde trekke van die vergelykingsontvanger deurlaat. In die voorbeeld: God is 'n eggenoot, word sekere eienskappe van die mens op God oorgedra terwyl ander eienskappe teruggehou word. Die metafoor betrek God en mens op mekaar. God word 'n eggenoot. Maar die metafoor handhaaf altyd 'n gesonde spanning tussen God en die eggenoot. Anders gesê: God gaan nie in die eggenoot op nie. Hy is oneindig groter en meer as net 'n eggenoot. Die metafoor skep nie net ' $n$ nuwe sinsamehang nie, maar stel ook grense. Wanneer metafore gebruik word, moet daar altyd na die 'wortelmetafoor' gesoek word, maar 'n mens moet ook op die uitkyk wees vir die elemente van die konteks wat nie deur metaforiese taalgebruik uitgedruk word nie.

Tradisioneel, maar ook in die algemeen gesien, is verskynsels soos metaforiek, hiperbool (oordrewe gevoelsuiting of die neerslag van 'n diep indruk), litotes (beklemtoning deur die ontkenning van die teenoorgestelde, verkleining of versagting) en ander middele 'stylfigure' wat uitsluitlik tot die wêreld van die poësie, die verbeelding en die retoriek behoort. Metafore en die ander genoemde stylfigure word beskou as retoriese middels wat hoofsaaklik bydra tot die stilistiese verfraaiing van literêre tekste (Carstens 1992:114).

Die betekenis van die metafoor staan nie klinkklaar vas nie en die uitwerking daarvan kan nie presies voorspel word nie. Metafore is 'ongebonde taal' (langage délié). Mense laat hulle nie deur die gangbare voorsê nie, maar skep betekenismoontlikhede wat tot nou toe nie ontgin is nie. Die lewende metafoor maak die taal nuut. Die vernuwing en nuwe insigte kom tot stand deurdat 'n metafoor normaalweg 'n woord of segging is wat binne 'n ongewone konteks gebruik word (Vos 2002:84-85).

Die metafoor is 'n vonk in die hand van die digter. Hy steek die wêreld daarmee aan die brand. Die metafoor stel hom in staat om die verrassende, die onopvallende, die skynbaar teenstrydige en ironiese te vind. ' $n$ Voorbeeld hiervan is:

Ons wil alles stil laat

sodat die onsigbare kan praat.

My tong swel rooi van plesier

oor lewende woorde op papier.

'n Metafoor is veral 'n instrument van die odd language - die religieuse taal (Vos 2002). Dit beteken egter nie dat religieuse taal uitsluitlik metafories is nie. In die teologie kan die aanhoudende gebruik van poëtiese, metaforiese taal 'n gevoel van vermoeidheid sowel as van verhewenheid oproep. En tog is daar in die gebruik van metaforiese taal die verrassende en verruklike.

\section{Funksies van 'n metafoor}

Aristoteles onderskei drie soorte woorde: vreemd, gewoon en metafories. Vreemde woorde gee ons hoofbrekens; gewone woorde dra oor wat ons reeds weet; dit is die metafoor wat iets nuuts en vars bied (Carson 1999:30).

Om die trefkrag, nuutheid en varsheid van metafore te peil, moet bepaalde funksies van hulle onderskei word.

\section{Die metafoor skep spanning}

'n Metafoor help om die onbekende in terme van die bekende te verstaan. Metafore dien nie net om iets te 'benoem' nie, maar dit verleen ook toegang tot dit waarna verwys word. Op dié manier word 'n brug, 'n tussenspel, tussen 'saak' en 'beeld' geskep. Deur die beeld word toegang tot die saak bewerkstellig.

Eie aan die metafoor is dat dit taalspanning skep (Ricoeur 1975:77, 79, 92-93, 95). Dit bied 'n 'stereoskopiese visie' 
en bind al twee die helftes, die saak en die beeld (bv. God en eggenoot, in Hos 1-3, en God en rots, in Ps 18:2) saam in 'n komplekse spanning wat sowel die ooreenkomste as die verskille erken. Só ontstaan 'n dinamiese interaksie tussen 'saak' en 'beeld'. Die interaksie by die gebruik van metafore vind nie slegs op woordvlak plaas nie, maar ook op betekenisvlak. Hierdie interaksie wat metafore bewerkstellig, skep ruimte vir verbeelding.

Die metafoor werk gelyktydig met die paradoks van dit wat is en ook nie is nie. Die spanningskwaliteit van 'n metafoor bevestig en ontken terselfdertyd dat iets die geval is. Daar is, volgens Ricoeur (1977:221-224, 255-256), 'n implisiete en 'n 'is ook nie', of ontkennende element, in elke positiewe metaforiese bewering. Black (1962:229) praat van die metafoor as 'n filter waardeur sommige eienskappe syg en ander agterbly. Daar is betekenisse van die eggenoot wat nie op God oorgeplaas kan word nie. 'n Mens kan nie verwag dat God soos 'n man of vrou in die huwelik optree nie.

Die metafoor God as 'n eggenoot bevestig dat daar 'n verband tussen God en 'n eggenoot gelê word (liefde, trou, opoffering), maar dit bewaar steeds die 'is nie'-element. God is nie in alle opsigte' $n$ eggenoot nie. Die verwysingsraamwerk van die hoorders, waarin hulle waarneem, lei daartoe dat die metafoor van 'God is eggenoot' assosiasies van liefde, trou en opoffering oproep. Op hierdie manier word nuwe perspektiewe op God en ervarings van Hom in die alledaagse lewe moontlik gemaak. Die metaforiese spanning word egter gehandhaaf deurdat God nie altyd in die alledaagse werklikheid as 'n 'eggenoot' ervaar word nie.

Dieselfde geld vir die metafoor God is ' $n$ rots. Dit bring assosiasies van vastigheid, betroubaarheid en beskerming na vore. Maar Hy is ook nie 'n rots nie. God is nie 'n ding wat gemaak is nie. Hy is en bly die lewende en sprekende God.

\section{Die metafoor verbind verwante werklikhede}

In die proses van metaforiese vervanging is die aandag gevestig op twee realiteite wat op een of ander manier met mekaar verband hou. In die voorbeelde wat hier gebruik word, verteenwoordig die aardse werklikheid God se werklikheid. Psalm 84:12 vermeld dat God 'n son is. Die son is vir die aarde lewegewend. Die metafoor dui daarop dat God vir diegene wat in opregtheid wandel, 'n son is. In Psalm 91:1 verklaar die digter dat hy in die skaduwee van die Almagtige vernag. Hiermee word die koelte en beskutting wat die Here gee, aangedui. Verder praat Psalm 91:4 van God se vleuels. Hierdie metafoor wys op God se sorg en beskerming.

\section{Die metafoor as netwerk}

Ricoeur (1977:44) wys daarop dat 'die primêre eenheid van betekenis' die sin en nie die woord is nie. As daar na metaforiese taal verwys word, gaan dit nie slegs om 'n funksie van woorde nie, maar ook om die totale ko(n)teks waarbinne woorde (frases) gebruik word. Onder konteks word nie net die literêre aspekte (d.w.s. makrostruktuur, diskoers, narratief, ens.) verstaan nie, maar ook ander 'mede'-tekste soos die onderwerp (d.w.s. skrywers sowel as lesers of hoorders), wat hul kultureel historiese agtergrond en literêre vaardigheid insluit. Talle metafore is nie tot 'n enkele teks beperk nie, maar oor die geskrif versprei. Die herdermetafoor in Psalm 23 moet ook met Jesaja 40:10-11 en Johannes 10:1-21 rekening hou.

\section{Konvensionele metafore}

Stylfigure soos metafore en vergelykings word soms gesien as uitdrukkings van buitengewone taalgebruik. Verder beskou sommige hierdie verskynsels as kenmerke slegs van taal, en nie ook as kenmerke van die menslike denke en handelinge nie (Vos 2002:88).

Metafore is egter nie net tot die teologie beperk nie. Dit is soos ons asem deel van ons ganse lewe. Dit deurdring ons denke en handelinge. Ons alledaagse sisteem van konsepte, wat ons denke en handelinge bepaal, is ten diepste metafories van aard (Lakoff \& Johnson 1980:3). Dit beteken dat alle taal deur konvensionele metafore deurspek is. Onder konvensionele metafore word metafore verstaan wat gegrond is in alledaagse ervarings wat gevolglik die wyse bepaal waarop mense dink en kommunikeer (Vos 2002:87). Metafore vorm 'n geskiedenis: dit kom uit 'n deurleefde geskiedenis en skep 'n nuwe geskiedenis.

\section{Metafoor se towerkrag}

Die metafoor beskik oor towerkrag. Dit kan aan 'n nuwe werklikheid vorm gee. Met behulp van die metafoor kan die liturg 'n towenaar word en in die erediens God se nuwe wêreld ontsluit. So kan mense geïnspireer word om die lig van God se nuwe wêreld hier en nou te laat deurbreek. In die liturgie moet die verhaal van die Bybel nie slegs herhaal word nie, maar veral herskryf word. God se bedoelings moet in vandag se tyd gelees en geleef word, en wel in 'n taal wat mense ontroer.

Die teoloog moet ook 'n woordkunstenaar wees, en mense boei. Daarvoor pleit Augustinus al in sy De doctrina Christiana $X 11,27$ waar hy noem dat een van die funksies van die preek delectare is. Die liturg kan humor ook sinvol gebruik. Egte humor is nie hard nie, maar vloeibaar. Humor stel die liturg in staat om deur litugiese taal die dodelike erns en hardheid van die lewe te versag (Vos 1996:198). Teoloë moet humor as 'menslike deug' bly beoefen. Daarsonder word hulle die prooi van 'teologiese hoogmoed' en word hulle die groot inkwisiteurs wat andersdenkendes wil uitwis (Schillebeeckx 1995:183). Humor is noodsaaklik want '... a sense of humor is not only a sign of humility but also the gospel's liberating power' (Long 1989:16). In liturgiese taal stel humor erediensgangers in staat om vir hul eie onbeholpenheid te lag. Die liturgie vertoon al te dikwels 'n nors gesig sonder warmte.

\section{Metafore in die teologiese gesprek}

Teologiese taal het 'n metaforiese straling. Daarom moet teologiese spreke ook 'n metaforiese gesig vertoon, anders is daar weinig te spreke tot of oor die Onsienlike. 
'n Metafoor is soos 'n paling: dit is glad, vinnig, ontglipbaar, verrassend en vars. Die uitdaging vir die teologie is om eerbiedig en in verwondering met metafore om te gaan.

\section{Homeros}

Twee sentrale metafore en van die oudstes wat die blinde digter Homeros (agtste eeuv C) in sy magistale Illias en die Odeusia gebruik, is stryd en reis (Manguel 2007:2). Die Illias beskryf die stryd van Agamennon om Helena te bevry wat deur Paris, die koning van Troje, gevange geneem is. Die stryd het 10 jaar geduur (Manguel 2007:9). Tien jaar na die val van Troje begin die Oddeusia (Manguel 2007:11, 25). Manguel (2007:214) wys daarop dat die Illias en die Odeusia op die twee grondmetafore van die menslike bestaan begrond is. Stryd (om oorlewing) en reis na Itakha (die toekoms, die droomland, die tuiste). In die Odeusia word die reis aangedryf deur heimwee wat die skip se seile laat bol.

\section{'n Lewensreis met 'n Psalmbundel}

Wat is die laaste boek wat ek inpak voor ek op reis gaan? Ek sal 'n klein digbundeltjie, Psalms 120-134, op my reis saamvat. Dit sal vir my soos brood wees. Soos manna uit die hemel.

Die eerste drie psalms (Psalms 120-122) in die klein digbundeltjie vertel hoe die reis verloop (vgl. Schuman 2008:59-60). In Psalm 120:5 roep iemand uit: 'Hoe ellendig was dit toe ek as vreemdeling in Mesek gewoon het ...' Eintlik weet ons nie waar om dié plek op 'n landkaart te soek nie. Mesek en Kedar staan vir onherbergsaamheid, onleefbaarheid en vervreemding. Hier ervaar iemand ongeluk in 'n vyandige gebied. Hier is haat, nyd en gevare. Die 'ek' van Psalm 120 soek na vrede, sjalom. 'Helaas, ek moet leef in Mesek ... té lank moes ek woon met heimwee.'

Ons ken as reisigers almal die ervaring van Mesek. Die land van vervreemding, ongeluk, eensaamheid. Die lewe knou ons af. Ons voel die seer en sien die kneusings. Daar is kommer, twyfel, aanvegtinge, droefheid, stryd en dood. Misdaad, geweld, onreg, kwaad. Ons proe die soet, maar veral ook die suur in Mesek.

Ons kan nie net in Mesek bly nie. Ons moet verder reis. Maar hoe? Die reisiger kyk rond. In die volgende lied, Psalm 121, kry die verhaal 'n vervolg. Hy kyk na die berge vir hulp. Die berge was destyds gesien as die blyplek van die gode (vgl. Prinsloo 1984:109-110). Ons hulp kom nie van die gode nie. In die lig van die teksgeheel waar daar ook na ander gode, die son en die maan, verwys word, kies ek die betekenis dat met 'die berge' in werklikheid 'die berge van Sion' bedoel word. Dáár is God teenwoordig (Hossfeld \& Zenger 2008:436-437) en met die oog op Hom, kan ons die lewensreis aanpak. Sion staan vir die verborgenheid van God en vir die seën wat van Hom uitgaan (Schuman 2008:110). God bly God en ons is sy geseëndes.

'My hulp kom van die Here.' Hy is die Maker van die hemel en die aarde. Hy sal die reisiger beskerm en bewaar. Die Here slaap nooit nie en Hy sluimer nie in nie. Hy maak nie 'n oog toe nie. Hy sal die reisiger van alle gevare bewaar. Die son en die maan het vir die reisiger dodelike bedreigings ingehou. 'n Dienaar het 'n sonskerm oor die Assiriese koning gehou om hom teen sonsteek te beskerm. Net so beskerm die

Here ons teen die dodelike son. Ons reis onder sy skaduwee. Die maan het malaria en melaatsheid gebring. Teen dié gevare beskerm die Here ons op ons reis.

Waarheen lei ons reis? Hierop antwoord Psalm 122:1-2: 'Ek was bly toe hulle vir my gesê het: "Kom ons gaan na die huis van die Here toe." En nou is ons binne-in jou, Jerusalem.' Van Mesek tot Jerusalem. Daar word die tuiskoms van reisigers gevier. Ons is dáár in die geselskap van 'n feesvierende skare. Uit Mesek, oor die berge en gevare, na die stad van vrede, na Jerusalem toe. Daar is God in sy heerlikheid.

Dis nag. Die tyd van afskeid ná die godsdienstige fees. Maar voordat die pelgrims die nagrus opsoek, om dan môre vroeg die terugtog na hul dorpe en stede aan te pak, gee hulle 'n opdrag aan die diensdoenende priesters en Leviete. Hulle versoek die priesters en Leviete om die Here in 'n naglied te seën.

Wat maak ons as reisigers in die Here se teenwoordigheid? Ons is daar om die Here te seën. Hy wag op ons seën. Die doelwit van die liturgie is om God te seën, om Hom te prys. Prys Hom met jou gebed, lied en musiek.

Die tweede liturgiese handeling (Psalm 134:3) is in die vorm van 'n gebed. Dit is die antwoord van die priester. Die Here se lewensbeskerming en lewenshulp kom uit Sion. Op die pad neem hulle die Here se seën as sy geskenk saam. Dié seën wat hulle ook aan mekaar in die alledaagse lewe moet uitdeel.

Ons lewensreis lê voor. Maar voordat ons gaan, moet ons eers wag. Wag vir die seën. 'Mag die Here jou seën ...' Die Skeppergod wil aan ons sy nabyheid gee. Hy wil aan ons lewensbeskerming en lewenshulp gee. Hy wil saam met ons op reis gaan. Op sy seën kan ons reken. Want Hy het die hemel en die aarde gemaak. Hy het die hemel opgeslaan soos ' $n$ blou tentdoek wat deur die wind vol kreukels gewaai word. Hy het die aarde soos ' $n$ ronde bal in die niks laat hang. Hy laat sy skepping nie los nie. Hy hou die skepping in sy hand. En Hy hou sy seën soos vlerke oor ons. Die Here se seën is asem, lewe, liefde, kos, sorg. Met sy seën kan ons op reis gaan. Ons moet die seën ook elke dag aan mekaar uitdeel.

Uit die mond van die Nuwe Testament hoor ons ook 'n seëngebed. 'Mag die genade van die Here Jesus Christus met julle wees ...' Jesus Christus se seën is dit wat Hy deur sy lewe en sterwe gedoen het. Hy het vrede en versoening gebring. Ons moet dit in die liturgie vier en in die preek vertel. 'Mag die liefde van God met julle wees ... God se seën is sy liefde wat soos vlerke oor jou oopvou. Sy liefde dra jou wanneer jy swaarkry en siek is.' 
Die liturgie moet 'n liefdesruimte en die preek 'n liefdesverklaring wees. 'Mag die gemeenskap van die Heilige Gees met jou wees.' Die Heilige Gees laat ons in die Here se seën deel. Hy laat jou God ervaar.

Ons is geseëndes van die Here. Daarom kan ons op reis gaan. 'Mag die Here ons seën uit Sion. Mag die genade van Jesus Christus, die liefde van God en die gemeenskap van die Heilige Gees met ons as reisgers wees.'

\section{'n Reis op die nou pad}

Aangesien metaforiek nie net in taal uitmond nie, skep dit ook op denk- en handelingsvlak nuwe moontlikhede en uitsigte (Vos 2002:87).

Hierdie siening van die metafoor kan aan die hand van 'n voorbeeld uit die Nuwe Testament toegelig word. In Matteus 7:13 en 14 staan daar: 'Gaan deur die nou poort in. Die poort wat na die verderf lei, is wyd en die pad daarheen breed, en diegene wat daardeur ingaan, is baie. Maar die poort wat na die lewe lei, is nou en die pad daarheen smal, en diegene wat dit kry, is min.'

Hoewel dit onwaarskynlik is dat die skrywer van die evangelie volgens Matteus die lewe as 'n reis sien, is sy denke tog in 'n groot mate deur die metafoor bepaal (Vos 2002:88). Die metafoorkonsep kom neer op 'n verbinding waarin 'n konsep (die lewe) verstaan word deur middel van 'n ander konsep ('n reis) (Liebenberg 2001:98). 'n Metafoor kry geldigheid deur die gebruik daarvan in alledaagse taal en denke. Om die funksie daarvan te verstaan, moet ' $n$ mens op hoogte wees van die wyse waarop die metafoor gebruik word en vasgelê is (Vos 2002:88).

Die metaforiese skakeling of koppeling van twee konsepte word moontlik gemaak deur die generiese struktuurvlak wat dit gemeen het (Vos 2002:88). Hierdie teoretiese uitleg kan deur twee voorbeelde toegelig word. In Matteus 7:13 en 14 is die reisger nie identies aan die pad waarop hy of sy reis nie. Net so is die lewe van die persoon nie identies aan sy of haar doel, naamlik toegang tot die koninkryk nie. In Johannes 14:1-6 word die weg en die reisiger, en voorloper, egter in die figuur van Jesus met mekaar verenig. Hy is die een wat weggaan om die voorbereiding te tref. Sy weg is aan die dissipels bekend, en verder is Hy self ook die weg (Liebenberg 2001:144v.).

Die begrensing van metaforiese koppeling hang saam met ons ervaringe en die manier waarop dit ons denke oor konsepte vorm (Liebenberg 2001:115). Met behulp van beeldskemas verstaan ons nie slegs metafore nie, maar ook dit wat ons gewoonlik in die wêreld aantref (Johnson 1987:xiv). Beeldskemas is naas denk-'beelde' ook enige konsep waaroor ons beskik om ons byvoorbeeld 'n weg of 'n reis voor te stel. Ons beskik slegs oor die konseptuele begrip van 'n reis as metaforiese uitdrukking van 'n lewe en ons kan die begrip op die taalgebruik toepas en herskik (Vos 2002:88).
Die uitdrukking 'die lewe is 'n reis' bied 'n voorbeeld van 'n konvensionele metafoor. In die Palestina van die eerste eeue lei 'n breë pad en 'n groot hek na 'n positiewe bestemming, miskien selfs na 'n groot stad (Vos 2002:88). Die metaforiese koppeling van die konvensionele metafoor 'die lewe is ' $n$ reis' roep na verwagting 'n positiewe kant van die breë pad en die hek op. Die beeldskema van die assosiasie met pad en hek sluit waarskynlik 'n gunstige bestemming in. In Matteus 7:13 en 14 kom 'n herinterpretasie voor van die konsep 'lewe' wat gewoonlik as ' $n$ reis gesien word. Die verwagting is dat die reisiger die breedste en maklikste pad sal kies. Maar die lewe as ' $n$ reis is in hierdie teks allesbehalwe normaal. Die reisiger op pad na die koninkryk kies die moeilikste pad, die smal pad. Die konsep 'lewe' word hier gestruktureer op grond van die beeldskema van ' $n$ reis waar keuses wat hier en nou gemaak word, konsekwensies vir die uiteindelike bestemming het (Liebenberg 2001:122).

Konvensionele metafore verbind spesifieke skemavlakke soos lewe en reis aan mekaar. Maar daar bestaan ook 'n ander kategorie van konseptuele metafore, beter bekend as die generiese metafoorvlak (Liebenberg 2001:122). Elke beeldskema waarvan ons 'n konsep het, besit nie alleen 'n spesifieke struktuurvlak nie, maar ook 'n meer generiese struktuurvlak. Lakoff en Johnson (1989:81) beskryf dit nader aan die hand van die verskil tussen 'n genus en 'n soort in die biologie. 'n Genus is die kleinste groep diere of plante met gemeenskaplike eienskappe. 'n Soort daarenteen deel alle eienskappe van 'n genus, maar besit ook unieke bykomende eienskappe wat hom van ander soorte onderskei. Op soortgelyke wyse deel 'n spesifieke struktuurvlakmetafoor soos 'die lewe is ' $n$ reis' bepaalde eienskappe met ander spesifieke struktuurvlakmetafore, byvoorbeeld 'die lewe is ' $n$ dag lank'. Dan is daar weer sprake van eienskappe op generiese metafoorvlak. In dié verband kan gedink word aan progessie, 'n temporele begin en einde, verganklikheid, en so meer (Vos 2002:89).

Met behulp van beeldskemas verstaan ons nie slegs metafore nie, maar ook dit wat ons meestal in die werklikheid aantref. Beeldskemas is nie net denk-'beelde' nie, maar enige konsep waaroor ons beskik om die reis voor te stel.

\section{'n Reisgeselskap}

Hoe kan 'n hermeneutiese brug geslaan word tussen die Griekse wêreld, die Ou Testamentiese, die Nuwe Testamentiese omgewing en Julian Müller se reis? Die gemeenskaplike is die gebruik van die reismetafoor.

Die praktiese teoloog moet soek na metafore in die denke van mense om met elkeen van hulle as homo viator te kommunikeer. Hoe kan Müller se boek oor die gesinspastoraat uit die konvensionele metafoor put? Sy boek bied die sleutel. 'n Gesin is op reis. Saam op reis. Reis beteken kommunikasie (gesprek), 'n heersersvrye gesprek (Habermas). Die reis is ook 'n waagstuk (Vloemans). Om mens te wees beteken om langs die afgrond te reis. Daarom is daar sprake van lig en donker, val en opstaan, lyding en vreugde. Op die reis is daar 
vitaliteit, beweging, voorgang, landskap en konteks. Met die verandering van tye word die landskap anders gekleur. Al hierdie woorde hoort tuis in die praktiese teologie se woordeskat.

\section{'n Teologiese padkaart vir die reis}

Ek bepleit 'n heersersvrye preekaanbieding (vgl. Vos 1996: 11). Die Christologiese en pneumatologiese begronding van die teologie (in die geval die pastoraat) is ononderhandelbaar vir die reis. Dit beskerm die praktiese teologie teen subjektivisme en kontekstualisme. Op die reis moet daar oor die evangelie (goeie nuus) gepraat word. Die grondslag van die goeie nuus is die heil wat Christus sonder en buite ons (extra nos), maar vir ons (pro nobis) bewerk het. Die Heilige Gees deel die heil uit genade aan ons uit. Ons ontvang dit deur die geloof. Die Gees doen alles, maar nie sonder die mens nie (vgl. Vos 1996:104-120). Die mens is in die Gees se hand nie 'n stok en blok nie, maar 'n lewende en verantwoorde wese.

Die reis is in Müller se woorde 'n reis-geselskap. 'Die moontlikheid om te lewe, begin in die oë van die ander' (Houellebecq 2012). Deur die ander word ek mens. Emmanuel Levinas het ook klem gelê op die onontbeerlikheid van die ander (Van Riessen 1991:240-241). Die reismetafoor skep spanning. Waar mense saamreis, is daar altyd sprake van spanning en konflik, val en opstaan. Maar daar is ook ruimte vir gesprek (woord en weerwoord) en om saam in die geselskap van die ander te reis. Verskillende woordassosiasies is soos brood op die reis. Die metafoor wys nuwe paaie aan. Om die draai wag die verrassende, die onvoorspelde, die onverwagte, die toekoms. Die rede hiervoor is dat Jesus weggegaan het om die voorbereiding te tref. Sy weg is aan ons bekend, en voorts is Hy die weg na die Vaderhuis (Joh 14:6).

\section{'n Gedig vir die reis}

\section{Reis}

met sy oor op die grond en sy hand voor die mond hoor hy mense mompelfluister dat alle lewensin verduister miskien, wie weet, loop daar tog 'n spoor van hoop jy is met jou geselskap op reis verby sterre tot in die Vaderhuis.

\section{Erkenning Mededingende belange}

Die outeur verklaar dat hy geen finansiële of persoonlike verbintenisse het met enige partye wat hom nadelig of voordelig kon beïnloed het in die skryf van hierdie artikel nie.

\section{Literatuurverwysings}

Black, M., 1962, Models and Metaphors: Studies in Language Philosophy, Cornell University Press, London.
Bons, E., 2004, 'Die Ehemetphorik in Hosea 2,4-25 - Elemente, Funktion, Hintergrunde', in $\mathrm{H}$. Irsigler (red), Mytisches in biblicher Bildsprache: Gestalt und Verwandlung in Prophesie und Psalmen, n.p. Herder Verlag, Freiburg.

Carson, A., 1999, Economy of the Unlost, Princeton University Press, Princeton.

Carstens, A., 1992, 'Metonimie, polisemie en die leksiografie', Suid-Afrikaanse Tydskrif vir Taalkunde 10(3), 114-122.

Degenaar, J., 1970, 'lets oor die metafoor', Tydskrif vir Geesteswetenskappe 10(4), 293-322.

Degenaar, J., 2011, Power of Imagination, GRAFIXIT, Stellenbosch.

Dreyer, P.S. \& Schoeman, S.J., 1964, Homo Viator. Feesbundel aangebied aan prof C.K. Oberholzer, HAUM, Pretoria.

Du Plessis, J.G., 2006, 'Die metafoor op die markplein', in D. Hertzog, E. Britz \& A. Henderson (reds.), Gesprek sonder grense, bl. 73-86, H\&B Uitgewers, Stellenbosch.

Fenton, J., 2003, An introduction to english poetry, Penquin Books, England.

Goodman, N., 1968, Languages of art: An approach to a theory of symbols, The Bobbs-Merril Co, Indianapolis-New York-Kansas City.

Görg, M., 2004, 'YHWH als Ehemann und als Löwe: Ambivalenz und Kohärenz in der Metaphorik des Hoseabuches', in Schriftprophetie. Festschrift für Jörg Jeremias zum 65. Geburtsdag, n.p., Neukirchen Verlag, Neukirchen-Vluyn.

Gräbe, I., 1992, 'Metafoor', in T.T. Cloete (red.), Literêre terme en teorieë, bl. 288-293, HAUM, Pretoria.

Heitink, G., 1993, Praktische Theologie. Geschiedenis - theorie - handelingsvelden, Kok, Kampen.

Heitink, G., 2011, Golfslag van de tijd. Europa's niet te stllen verlangen naar God, Kok, Kampen.

Heubeck, A. \& Hoekstra, A., 1989, A Commentary on Homer's Odyssey. Volume II. Books IX - XVI, Oxford University Press, Oxford.

Hirsch, E., 1999, How to read a poem and fall in love with it, Harvest Books, San Diego.

Houellebecq, M., 2012, Tagtig gedigte en twee essays, vertl. uit die Frans deur Catherine du Toit en medewerkers, Hond Bk, Pretoria.

Hossfeld, F.L. \& Zenger, E., 2008, Psalmen 101-150, Herder Verlag, Freiburg-BaselWene.

Johnson, M., 1987, The body in the mind: The bodily basis of meaning, Chicago Press, Chicago.

Lakoff, G. \& Johnson, M., 1980, Metaphors we live by, University Chicago Press, Chicago \& London.

Liebenberg, J., 2001, The Language of the Kingdom of Jesus, Walter de Gruyter, Berlin. Long, T.G., 1989, The Witness of Preaching, John Knox Press, Louisville, Kentucky.

Manguel, A., 2007, Homer's the lliad and the Odyssey, Douglas \& McIntyre, Vancouver/Toronto.

Mehler, J., 1962, Mehler Woordenboek op de gedichten van Homeros, Uitgeverij Nijgh \& Van Ditmar, Rotterdam.

Müller, J., 2000, Reis-geselskap. Die kuns van verhalende pastorale gesprekvoering, Lux Verbi BM, Wellington.

Paglia, C., 2005, Break, blow, burn, Pantheon Books, New York.

Prinsloo, W.S., 1984, Van kateder tot kansel, NG Kerkboekhandel, Pretoria.

Ricoeur, P., 1975, 'Biblical Hermeneutics', Semeia 4, 29-145.

Ricoeur, P., 1977, The rule of metaphor: Multi-disciplinary studies in the creation of meaning in language, transl. by Robert Czerny with Kathleen McLaughlin and John Costello, Routledge \& Kegan Paul, London.

Richards, I.A., 1936, The Philosophy of Rhetoric, Oxford University Press, New York.

Schillebeeckx, E., 1995, Theologisch testament. Notarieel nog geen verleden, Ten Have, Baarn.

Schoeman, M., 2004, Generositeit en lewenskuns. Grondtrekke van 'n postNietzcheaanse etiek, Fragmente Uitgewers, Pretoria.

Schuman, N.A., 2008, Drama van crisis en hoop: De psalmen: Gedicht, gebundeld en gebeden, Meinema, Zoetermeer

Sharpe, R.A., 1995, Oxford Companion to Philosophy, Oxford University Press, New York.

Stanford, W.B., 1962, The Odyssey of Homer, Books XIII-XXIV-XXIV, Macmillan \& Co Ltd, London.

Stanford, W.B., 1964, The Odyssey of Homer, Books I-XII, Macmillan \& Co Ltd, London.

Van Riessen, R., 1991, Erotiek en dood. met die oog op transcendentie in de filosofie van Levinas, Kok Agora, Kampen.

Vloemans, A., 1949, De mens als waagstuk. Filosofische Anthropologie, H.P. Leopolds Uitgevers-mij N.V., Den Haag.

Vos, C.J.A., 1996, Die volheid daarvan 1 en 11, RGN Uitgewers, Pretoria.

Vos, C., 2002, 'Liturgische taal als metaforische taal', in Barnard, Marcel en Schuman, Niek (reds.), Nieuwe wegen in de liturgie. De weg van de liturgie - een vervolg, n.p., Meinema, Zoetermeer.

Vos, C.J.A., 2005, Theopoetry of the Psalms, T\&T Clark, London,

Vos, C., 2012, Weerloos lewe, Protea Boekhuis, Pretoria.

Wolterstorff, N.P., 1999, Cambridge Dictionary of Philosophy, Cambridge University Press, Cambridge. 